\title{
Communication
}

[Comunicação]

\section{Quality of fermented milks produced with Lactobacillus rhamnosus and Lactobacillus fermentum isolated from artisanal cheeses}

[Qualidade de leites fermentados produzidos com Lactobacillus rhamnosus $e$ Lactobacillus fermentum isolados de queijos artesanais]

\author{
D.P.G. Mendes ${ }^{1}$, M.R. Souza ${ }^{2}$, M. Galletti Júnior ${ }^{3}$, M.O. Leite ${ }^{2}$, C.F.A.M. Penna ${ }^{2}$ \\ ${ }^{1}$ Aluna de pós-graduação - Escola de Veterinária - UFMG - Belo Horizonte, MG \\ ${ }^{2}$ Escola de Veterinária - UFMG - Belo Horizonte, MG \\ ${ }^{3}$ Aluno de graduação - Escola de Veterinária - UFMG - Belo Horizonte, MG
}

Several types of fermented milks, elaborated with lactic acid bacteria (LAB), are found in the market throughout the world. The consumption of these foods has been increased and consumers are selecting these products especially due to flavor and beneficial aspects related to health (Viegas et al., 2010)

Most fermented milks contain Lactobacillus spp. which are Gram positive, catalase negative, microaerophilic or anaerobic rods. They have been found in the gastrointestinal tract of human beings and other animals as well in fermented foods (Jay, 1996).

L. rhamnosus belongs to $L$. casei group. Jay (1996) described L. rhamnosus as isolated rod cells that may form chains. They show obligatory heterofermentative metabolism and produce lactic acid.

Lactobacillus fermentum is the main obligatory heterofermentative Lactobacillus species found in the digestive tract of humans, and it is also used by the dairy industry as starter culture (Dickson et al., 2005).

The use L. fermentum and L. rhamnosus for production of fermented milks is very common in Europe, but not in Brazil. Thus, the aim of this work was to elaborate fermented milks using $L$. fermentum and L. rhamnosus isolated from Brazilian artisanal cheeses and evaluate their physical-chemical, microbiological and sensory characteristics. In the future, it may bring benefits to the development of novel dairies and reduce the need for using imported cultures by the national industries.

Three batches of powder milk were used to produce the fermented milks. The quality of those products was determined by the following physical-chemical analyses: determinations of $\mathrm{pH}$, titratable acidity and percent contents of fat, protein and moist (Brasil, 2006). The powder milk was also submitted to microbiological analyses including: counts of aerobic mesophilic microorganisms and molds and yeasts; determination of the Most Probable Number (MPN) of total and thermal tolerant coliforms and researches of Staphylococcus spp. and Salmonella spp. (Brasil 2003). All analyses were carried out in duplicate.

L. rhamnosus and L. fermentum used as starters were formerly identified using PCR ARDRA $16 \mathrm{~S}-23 \mathrm{~S}$ by Guedes Neto et al. (2005), who also demonstrated their in vitro probiotic properties including antimicrobial sensitivity and antagonistic activity.

Recebido em 6 de maio de 2013

Aceito em 19 de fevereiro de 2014

*Autor para correspondência (corresponding author)

E-mail: marceloresende51@gmail.com 
A volume of $100 \mu \mathrm{L}$ of thawed L. rhamnosus and L. fermentum cultures were transferred to $5 \mathrm{~mL}$ of MRS (Difco, Detroit, MI) broth, which were incubated at $37^{\circ} \mathrm{C} \pm 2^{\circ} \mathrm{C}$ for $24 \mathrm{~h}$. It was done twice to guarantee the activation of the bacteria. After that, each culture was inoculated at $3 \%$ in skim powder milk reconstituted at $10 \%$, added with $8 \%$ sucrose, heated at $110^{\circ} \mathrm{C}$ for $10 \mathrm{~min}$ and cooled at $37^{\circ} \mathrm{C}$. Then, they were incubated at $37^{\circ} \mathrm{C} \pm 2^{\circ} \mathrm{C}$ until coagulation. The fermented milks were stored from 8 to $10^{\circ} \mathrm{C}$ in a refrigerator (Ormifrio Ltda GCI004, Sabará, MG, Brazil).

Physical-chemical and microbiological analyses were carried out on days $1,15,30$ and 45 of storage. The $\mathrm{pH}$ was determined by digital $\mathrm{pH}$ meter (mPA-210, Piracicaba, SP, Brazil). Titratable acidity was expressed in grams of lactic acid per $100 \mathrm{~g}$ of product (International..., 1991). Fat content was obtained by Gerber method (Brasil, 2005). Contents of moist were determined using a heater (Biomatic, Porto Alegre, Rio Grande do Sul, Brazil) device and a balance (SHIMADZU AY220, São Paulo, SP, 37 Brazil), according to Brazil (2006). Protein content was determined by micro-Kjedahl, using the TECNAL (TE012, Piracicaba, SP, Brazil) device, according to Brasil (2006). Counts of LAB (CFU/ml) were carried out on MRS agar (Difco, Detroit, MI, United States), according to IDF (International..., 1988). Counts of molds and yeasts and determination of MPN of total and thermal coliforms were performed following Brasil (2003).

Sensory analyses of the fermented milks were carried out at 15 and 60 days of storage at $8-10^{\circ} \mathrm{C}$. Products were evaluated by a team of 30 non-trained tasters. They were selected according to availability and interest to participate coupled with the habit of intake fermented milks. The samples were codified with random sequences of three numbers and served to tasters in cabins designed for sensory evaluation. Each taster received a $20 \mathrm{ml}$-serving of fermented milk at 8 to $10^{\circ} \mathrm{C}$, inside opaque disposable plastic cups. The tasters also received a file that contained a 5points hedonic scale, which allowed them to express how they approved the fermented milks. The experiment was approved by the Research Ethics Committee at the UFMG (COEP), under the registration code ETIC 155/10.

The means of the physical-chemical analyses and counts of LAB were compared by the StudentNewman-Keuls test, at $5 \%$ level of significance. The results of sensory evaluation were submitted to non-parametric analyses using the Wilcoxon test, at $5 \%$ level of significance.

All the results of physical-chemical and microbiological analyses of the three batches of skim powder milk were in accordance with the standards established by the Brazilian legislation (Brasil, 1996). Hence, they showed appropriate quality to be used for fermented milks processing.

There was no difference $(\mathrm{P}>0.05)$ for the values of pH (Table 1) and titratable acidity (Table 2) of the fermented milks during the 45 days of storage under refrigeration. Values of $\mathrm{pH}$ decreased while values of titratable acidity increased with time, as expected. It was also verified by Viegas et al. (2010) during 40 days of storage of fermented milks elaborated with Lactobacillus acidophilus and Weissella confusa.

The similarity of $\mathrm{pH}$ and titratable acidity between the fermented milks may be related to the obligatory heterofermentative metabolism of the used $\mathrm{LAB}$, which produces $\mathrm{CO}_{2}$, lactic and acetic acids and ethanol from hexoses and lactic and acetic acids from pentoses (Jay, 1996).

Table 1. Mean percentage results of $\mathrm{pH}$ of Lactobacillus rhamnosus and Lactobacillus fermentum fermented milks in three batches stored at $8-10^{\circ} \mathrm{C}$, for 45 days

\begin{tabular}{cccccc}
\hline Fermented Milk & \multicolumn{3}{c}{ Days } & \multirow{2}{*}{ Means } \\
\cline { 2 - 5 } & 1 & 15 & 30 & 45 & \\
\hline LR & 4.68 & 4.43 & 4.13 & 4.14 & 4.35 \\
LF & 4.63 & 4.49 & 4.19 & 4.18 & 4.37 \\
\hline
\end{tabular}

LR: milk fermented by Lactobacillus rhamnosus; LF: milk fermented by Lactobacillus fermentum. 
Table 2. Mean percentage results of titrable acidity of Lactobacillus rhamnosus and Lactobacillus fermentum fermented milks in three batches stored at $8-10^{\circ} \mathrm{C}$, for 45 days

\begin{tabular}{cccccc}
\hline \multirow{2}{*}{ Fermented Milk } & \multicolumn{3}{c}{ Days } & Means \\
\cline { 2 - 5 } & 1 & 15 & 30 & 45 & \\
\hline LR & 0.65 & 0.69 & 0.93 & 1.03 & 0.82 \\
LF & 0.60 & 0.66 & 0.91 & 1.06 & 0.81 \\
\hline
\end{tabular}

LR: milk fermented by Lactobacillus rhamnosus; LF: milk fermented by Lactobacillus fermentum.

There was no difference $(\mathrm{P}>0.05)$ in protein (Table 3) contents of both fermented milks throughout the time, which averaged $3.38 \%$. The obtained values were in accordance with the Brazilian legislation (Brasil, 2007).

All fermented milks presented $0 \%$ of fat during all evaluated times corroborating with the type of powder milk used to their preparation.

There were not differences $(\mathrm{P}>0.05)$ in relation to the contents of moist (Table 4) when comparing the batches of either L. rhamnosus or L. fermentum fermented milks throughout the time.

Brazilian legislation (Brasil, 2007) establishes minimum values for counts of LAB in fermented milks and they should be accomplished throughout the shelf-life. Minimum counts are
$10^{7}$ and $10^{6} \mathrm{CFU} / \mathrm{g}$ for acidophilus milk and fermented milks, respectively. During the 45 days of storage, all fermented milks elaborated in this work showed LAB counts equal or higher than $10^{8} \mathrm{CFU} / \mathrm{g}$ (Table 5). In order to guarantee the possible probiotic effects, those bacteria must be viable and present in high concentrations throughout the shelf-life.

Lactobacillus rhamnosus fermented milks and Lactobacillus fermentum fermented milks showed similar $(\mathrm{P}>0.05)$ counts of LAB (Table 5) throughout the time. Despite the increase of acidity on the $45^{\text {th }}$ day of storage, counts of LAB reached values that point out to a good tolerance of them to the presence of acid compounds. It also shows that the fermentation process continued during the refrigeration storage, but in a lower rate.

Table 3. Mean percentage results of protein content of Lactobacillus rhamnosus and Lactobacillus fermentum fermented milks in three batches stored at $8-10^{\circ} \mathrm{C}$, for 45 days

\begin{tabular}{cccccc}
\hline Fermented Milk & \multicolumn{3}{c}{ Days } & \multirow{2}{*}{ Means } \\
\cline { 2 - 5 } & 1 & 15 & 30 & 45 & \\
\hline LR & 3.56 & 3.45 & 3.29 & 3.22 & 3.38 \\
LF & 3.52 & 3.43 & 3.30 & 3.25 & 3.38 \\
\hline
\end{tabular}

LR: milk fermented by Lactobacillus rhamnosus; LF: milk fermented by Lactobacillus fermentum.

Table 4. Mean percentage results of moist content of Lactobacillus rhamnosus and Lactobacillus fermentum fermented milks in three batches stored at $8-10^{\circ} \mathrm{C}$, for 45 days

\begin{tabular}{cccccc}
\hline Fermented Milk & \multicolumn{3}{c}{ Days } & \multirow{2}{*}{ Means } \\
\cline { 2 - 5 } & 1 & 15 & 30 & 45 & \\
\hline LR & 82.60 & 83.26 & 83.90 & 84.85 & 83.65 \\
LF & 83.19 & 81.84 & 83.05 & 82.94 & 82.76 \\
\hline
\end{tabular}

LR: milk fermented by Lactobacillus rhamnosus; LF: milk fermented by Lactobacillus fermentum.

Table 5. Mean counts (CFU/g) of Lactobacillus rhamnosus and Lactobacillus fermentum in three batches of fermented milks stored at $8-10^{\circ} \mathrm{C}$, for 45 days

\begin{tabular}{|c|c|c|c|c|c|}
\hline \multirow{2}{*}{$\begin{array}{l}\text { Fermented } \\
\text { milk }\end{array}$} & \multicolumn{4}{|c|}{ Days } & \multirow[t]{2}{*}{ Means } \\
\hline & 1 & 15 & 30 & 45 & \\
\hline LR & $1.0 \times 10^{10}$ & $2.2 \times 10^{11}$ & $1.9 \times 10^{9}$ & $1.5 \times 10^{11}$ & $9.6 \times 10^{10}$ \\
\hline $\mathrm{LF}$ & $5.4 \times 10^{9}$ & $1.7 \times 10^{10}$ & $8.3 \times 10^{8}$ & $6.5 \times 10^{10}$ & $2.2 \times 10^{10}$ \\
\hline
\end{tabular}

LR: milk fermented by Lactobacillus rhamnosus; LF: milk fermented by Lactobacillus fermentum. 
Hekmat, Soltani and Reid (2009) studied milks fermented by L. rhamnosus and Lactobacillus reuteri during refrigerated storage and verified that L. rhamnosus was more stable with counts ranging from $10^{7}$ to $10^{8} \mathrm{CFU} / \mathrm{g}$, in spite of the increase of acidity and decrease of $\mathrm{pH}$.

Total and thermal coliforms as well molds and yeasts were not found in the fermented milks prepared in this study, demonstrating a quality higher than that required by the Brazilian legislation (Brasil, 2007) and appropriate hygienic processing and storage conditions.

Sensory evaluation (Viegas et al., 2010) of the fermented milks at 15 days of storage at $8-10^{\circ} \mathrm{C}$, using the 5-points hedonic scale, showed no difference $(P>0,05)$ between the products, since both reached similar values of medians. correspondent to acceptance grade of "like".
The medians of the sensory analyses of fermented milks stored for 60 days corresponded to the acceptance grade "neither like nor dislike". When comparing both products at that date, $L$. fermentum fermented milk had a better acceptance than L. rhamnosus fermented milk, which was due to a lower acidity found in the former.

It may be concluded that is possible to produce novel fermented milks using either L. rhamnosus or L. fermentum isolated from Brazilian artisanal cheeses. Those products may have a shelf-life of 45 days when stored at $8-10^{\circ} \mathrm{C}$.

Keywords: fermented milks, Lactobacillus spp., sensory evaluation, shelf-life

\section{RESUMO}

Leites fermentados por Lactobacillus rhamnosus e Lactobacillus fermentum, isolados de queijos artesanais, foram produzidos e avaliados quanto às características físico-químicas e microbiológicas durante 45 dias de estocagem a $8-10^{\circ} \mathrm{C}$. Análises sensoriais foram realizadas aos 15 e 60 dias. Ambos os leites fermentados apresentaram contagens adequadas das bactérias láticas, superiores a $10^{8} \mathrm{UFC} / \mathrm{g}$, durante toda a estocagem. As médias das análises físico-químicas e microbiológicas dos produtos durante a estocagem foram iguais e todos atenderam às especificações da legislação brasileira. Melhores resultados de avaliações sensoriais $(P<0.05)$ foram aos 15 dias de estocagem. Leites fermentados por L. fermentum obtiveram melhor aceitação sensorial aos 60 dias de estocagem, quando apresentavam acidez titulável inferior à encontrada no leite fermentado por L. rhamnosus. Portanto, a utilização dessas culturas pode ser viável para a elaboração de novos leites fermentados, que apresentariam prazo de validade de 45 dias de estocagem sob refrigeração.

Palavras-chave: leites fermentados, Lactobacillus spp., avaliação sensorial, estocagem

\section{ACKNOWLEDGEMENT}

The authors thank FAPEMIG for the financial support.

\section{REFERENCES}

BRASIL. Ministério da Agricultura e do Abastecimento. Secretaria de Defesa Agropecuária. Departamento de Inspeção de Produtos de Origem Animal. Portaria $n^{\circ} 146$ de 07/03/1996. Regulamento Técnico de Identidade e Qualidade de Leite em Pó. Brasília, 1996.

BRASIL. Ministério da Agricultura e do Abastecimento. Secretaria de Defesa Agropecuária Instrução Normativa $n^{\circ} 62$ de 26/08/2003. Métodos Analíticos Oficiais para Análises Microbiológicas para Controle de Produtos de Origem Animal e Água. Brasília, 2003.
BRASIL. Ministério da Saúde. Agência Nacional de Vigilância Sanitária. Instituto Adolfo Lutz. Métodos Físico-Químicos para Análise de Alimentos. Brasília, 2005. $1018 \mathrm{p}$.

BRASIL. Ministério da Agricultura e do Abastecimento. Secretaria de Defesa Agropecuária. Instrução Normativa $\mathrm{n}^{\circ} 68$ de 12/12/2006. Métodos Analíticos Oficiais Físico-Químicos para Controle de Leite e Produtos Lácteos. Brasília, 2006.

BRASIL. Ministério da Agricultura e do Abastecimento. Secretaria de Defesa Agropecuária. Departamento de Inspeção de Produtos de Origem Animal. Instrução Normativa $\mathrm{n}^{\circ} .46$ de 23/10/2007. Regulamento Técnico de Identidade e Qualidade de Leites Fermentados. Brasília, 2007. 
DICKSON, E.M.; RIGGIO, M.P.; MACPHERSON, L. A novel species-specific PCR assay for identifying Lactobacillus fermentum. J. Med. Microbiol., v.54, p.299-303, 2005.

GUEDES NETO, L.G.; SOUZA, M.R.; NUNES, A.C. et al. Atividade antimicrobiana de bactérias ácidolácticas isoladas de queijo coalho artesanal e industrial frente a microrganismos indicadores. Arq. Bras. Med. Vet. Zootec., v.57, p.245-250, 2005.

HEKMAT, S.; SOLTANI, H.; REID, G. Growth and survival of Lactobacillus reuteri RC-14 and Lactobacillus rhamnosus GR-1 in yogurt for use as functional food. Inn. Food Sci. Emerg. Technol., v.10, p.293-296, 2009.
INTERNATIONAL Dairy Federation - IDF. . Yogurt: Determination of titratable acidity. Bull. Int. Dairy Fed., v.150, p.1-2, 1991.

INTERNATIONAL Dairy Federation - IDF. Yogurt: Enumeration of characteristic microorganisms colony count technique at $37^{\circ}$. Bull. Int. Dairy Fed., v.117B, p.1-4, 1988.

JAY, J.M. Modern Food Microbiology. New York: Chapman \& Hall. 1996.

VIEGAS, R.P.; SOUZA, M.R.; FIGUEIREDO, T.C. et al. Qualidade de leites fermentados funcionais elaborados a partir de bactérias ácido-lácticas isoladas de queijo coalho de Pernambuco. Arq. Bras. Med. Vet. Zootec., v.62, p.460-467, 2010. 